\title{
Secondary Activation of a Cation Conductance Is Responsible for NMDA Toxicity in Acutely Isolated Hippocampal Neurons
}

\author{
Qiang X. Chen, ${ }^{1}$ Katherine L. Perkins, ${ }^{1}$ Dennis W. Choi, ${ }^{2}$ and Robert K. S. Wong ${ }^{1}$ \\ ${ }^{1}$ Department of Pharmacology, State University of New York Health Science Center, Brooklyn, New York 11203, and \\ 2Department of Neurology, Washington University School of Medicine, St. Louis, Missouri 63110
}

\begin{abstract}
One of the key questions concerning glutamate toxicity is how a transient NMDA exposure can lead to a delayed death of neurons. To address this issue, we performed whole-cell recording on acutely isolated hippocampal CA1 neurons to monitor the membrane response after NMDA exposure. Transient NMDA exposure (100 $\mu \mathrm{M}, 10 \mathrm{~min}$ ) induced an inward current (postexposure current; $I_{\mathrm{pe}}$ ) which was associated with a $\mathrm{Ca}^{2+}$. and $\mathrm{Na}^{+}$-permeable cation conductance. $I_{\text {pe }}$ continuously increased (in the absence of NMDA) until death of the neuron occurred. Application of NMDA in the absence of extracellular
\end{abstract}

calcium failed to trigger $I_{\mathrm{pe}}$ and neuronal death. Postexposure suppression of $I_{\text {pe }}$ protected against NMDA toxicity. These results indicate that a cation current, which is induced by an increase in intracellular calcium concentration $\left(\left[\mathrm{Ca}^{2+}\right]_{i}\right)$ and is itself partly carried by $\mathrm{Ca}^{2+}$, links the initial NMDA exposure to neuronal death.

Key words: NMDA; neurotoxicity; postexposure current; $I_{p e}$; excitotoxicity; calcium; hippocampus; glutamate; toxicity; cell death; neuronal death
Excess levels of the excitatory neurotransmitter glutamate can induce neuronal degeneration, primarily through NMDA receptor channel-mediated $\mathrm{Ca}^{2+}$ influx (Choi, 1988). Neuronal death associated with ischemia, hypoglycemia, trauma, and epilepsy can be reduced with antagonists of the NMDA type of glutamate receptor, suggesting the involvement of NMDA toxicity in these clinical conditions (Simon et al., 1984; Wieloch, 1985; Faden et al., 1989; Meldrum, 1994). However, the clinical utility of NMDA receptor antagonists faces a key impediment: the timing of treatment. The neuroprotective effect of NMDA receptor antagonists is significant only when administered before the insult (ischemia or transient NMDA exposure) or within a short window after the insult (Hartley and Choi, 1989; Graham et al., 1993). This short therapeutic window of NMDA receptor antagonists limits their usefulness and prompts the study of downstream mechanisms in the postexposure phase, the period between the initial transient NMDA exposure (exposure phase) and the death of neurons. During the postexposure phase, there is a secondary rise in intracellular calcium concentration $\left(\left[\mathrm{Ca}^{2+}\right]_{\mathrm{i}}\right)$, which is not reversed by NMDA antagonists (Randall and Thayer, 1992; Tymianski et al., 1993). This secondary rise in $\left[\mathrm{Ca}^{2+}\right]_{\mathrm{i}}$ is correlated with subsequent cell death (Randall and Thayer, 1992; Tymianski et al., 1993). Neither the secondary rise in $\left[\mathrm{Ca}^{2+}\right]_{i}$ nor the cell death occurs if the NMDA is applied in $\mathrm{Ca}^{2+}$-free solution (Randall and Thayer, 1992), suggesting that $\mathrm{Ca}^{2+}$ influx through NMDA receptor channels somehow triggers a process that causes the secondary rise in $\left[\mathrm{Ca}^{2+}\right]_{\mathrm{i}}$ and subsequent cell death. Suggested mechanisms for the secondary rise in $\left[\mathrm{Ca}^{2+}\right]_{i}$ include an increase in $\mathrm{Ca}^{2+}$ conductance, derangement of $\mathrm{Ca}^{2+}$ transport, and release of $\mathrm{Ca}^{2+}$ from intracellular stores (de Erausquin et al., 1990; Randall

\footnotetext{
Received Jan. 15, 1997; revised March 6, 1997; accepted March 12, 1997.

This work was supported by National Institutes of Health Grant NS 24682.

Correspondence should be addressed to Dr. Katherine L. Perkins, SUNY Health

Science Center, Box 29, 450 Clarkson Avenue, Brooklyn, NY 11203.

We are saddened by the passing of our colleague, Dr. Qiang X. Chen, and dedicate this article to his memory.

Copyright (C) 1997 Society for Neuroscience $0270-6474 / 97 / 174032-05 \$ 05.00 / 0$
}

and Thayer, 1992; Tymianski et al., 1993). In this paper, we have done electrophysiological recordings to monitor the membrane response after NMDA exposure and have determined that $\mathrm{Ca}^{2+}$ influx through NMDA receptors leads to the activation of a persistent $\mathrm{Ca}^{2+}$ - and $\mathrm{Na}^{+}$-permeable cation conductance that is responsible for the subsequent neuronal death.

\section{MATERIALS AND METHODS}

Whole-cell voltage-clamp recording was performed on acutely isolated hippocampal CA1 neurons. Neurons were prepared according to the Kay and Wong (1986) method, with the following modifications to increase the harvest of healthy neurons and preserve NMDA responses. Hippocampal slices were prepared by vibratome instead of tissue chopper, the $\left[\mathrm{Ca}^{2+}\right]$ in the incubation solution was reduced to $0.5 \mathrm{~mm}$ and the $\left[\mathrm{Mg}^{2+}\right]$ was increased to $7 \mathrm{mM}$, and 12-15 $\mu \mathrm{M}$ CPP (Tocris Cookson, St. Louis) was added during trypsin incubation of tissue slices to preserve the NMDA response (Chen and Wong, 1995a). Healthy neurons were selected for our experiments by choosing those that were uniformly bright under phase-contrast microscopy. These neurons have a normal (approximately $-60 \mathrm{mV}$ ) and stable resting potential within the first hour of recording, have an ability to fire action potentials, and show reversible receptor-channel modulation by second-messenger systems (Chen et al., 1990; Chen and Wong, 1995a,b).

Whole-cell voltage-clamp recording was performed using the procedure described by Hamill et al. (1981) with the use of a List EPC-7 patch-clamp amplifier (List Electronic, Darmstadt, Germany) and pClamp software (Axon Instruments, Foster City, CA). Access resistances were $\sim 10 \mathrm{M} \Omega$ and were compensated only in the experiments shown in Figure 2. Liquid junction potentials $\left(V_{\mathrm{lj}}\right)$ were measured using the procedure of Neher (1992). All potentials have been corrected for $V_{\mathrm{lj}}$, which ranged from 9 to $14 \mathrm{mV}$. Good recordings were ensured by discarding cells that had seal resistances $<20 \mathrm{G} \Omega$, that took more than three gentle sucks to break the membrane, or that did not maintain a stable input resistance during the first $5 \mathrm{~min}$ of recording before NMDA exposure. The holding potential was $-55 \mathrm{mV}$.

In one set of experiments, the intracellular perfusion technique was used to switch from control intracellular solution to high-calcium intracellular solution while recording from a single cell. For details of the intracellular perfusion method, see Chen et al. (1990).

Cells were in a $1 \mathrm{ml}$ bath that was perfused continuously with extracellular solution at a rate of $1-2 \mathrm{ml} / \mathrm{min}$. Extracellular control solution contained (in mM): $140 \mathrm{NaCl}, 2 \mathrm{KCl}, 2 \mathrm{CaCl}_{2}, 10 \mathrm{HEPES}, 0.01$ glycine, 25 
glucose, $\mathrm{pH}$ adjusted to 7.4 with $\mathrm{NaOH}$ (which raised the $\left[\mathrm{Na}^{+}\right]$to 145 $\mathrm{mM})$. Zero-calcium solution was the same as control solution, except with 0.5 BAPTA and no $\mathrm{CaCl}_{2}$. Application of NMDA and changes of ionic concentration around the recorded cells were achieved by a seven-barrel flow tube (Celentano and Wong, 1994). NMDA (100 $\mu \mathrm{M})$ was dissolved in control solution or zero-calcium solution as indicated. The $20 \mathrm{~mm}$ $\mathrm{NaCl}, 20 \mathrm{mM} \mathrm{KCl}$, and $10 \mathrm{mM} \mathrm{CaCl}_{2}$ solutions contained only the indicated ions, $10 \mathrm{~mm}$ HEPES, $0.01 \mathrm{~mm}$ glycine, $25 \mathrm{~mm}$ glucose, and sucrose added to preserve osmolarity. Intracellular control solution contained (in mM): $20 \mathrm{CsCl}, 100 \mathrm{CsOH}, 0.5 \mathrm{BAPTA}, 10 \mathrm{HEPES}, \mathrm{pH}$ adjusted to 7.2 with methane sulfonic acid. High-calcium intracellular solution was made by adding $1 \mathrm{mM} \mathrm{Ca}^{2+}$ to the control intracellular solution. The estimate of free $\mathrm{Ca}^{2+}$ in the high-calcium intracellular solution is $0.5 \mathrm{~mm}$ (Chen et al., 1990). The actual $\left[\mathrm{Ca}^{2+}\right]_{\mathrm{i}}$ reached because of perfusion of this solution, although likely to be $<0.5 \mathrm{~mm}$, is unknown. Chemicals were obtained from Sigma (St. Louis, MO) unless otherwise indicated.

Ionic activities were used for the calculation of relative permeabilities. To simplify the calculation of relative permeabilities, we assumed no significant effect from the surface charge on the permeation of cations. We also assumed that both the ionic composition around the intracellular side of the membrane and the relative permeability of the membrane were unchanged during the experiment. We used cells in which the $I_{\mathrm{pe}}$ was less than $-1 \mathrm{nA}$ in obtaining data for the evaluation of the relative permeability of the $I_{\mathrm{pe}}$ channel, because as $I_{\mathrm{pe}}$ increased in amplitude, extracellular ions accumulated around the intracellular side of the membrane as indicated by the gradual negative shift in the reversal potential when the amplitude of $I_{\mathrm{pe}}$ exceeded $-1 \mathrm{nA}$.

Trypan blue stain was used to assess cell death. Staining was performed by a $5 \mathrm{~min}$ bath perfusion of dye solution $(0.4 \%$ final concentration, made up in extracellular control solution). Neurons were examined for stain under bright-field microscope 5 min after changing back to control bath perfusion.

In some experiments, cell death was assessed in nonrecorded cells. For these experiments, cells were isolated from a single animal and put in several dishes called "sister dishes." Dishes were prescored into square fields with a $5 \mathrm{~mm} \times 5 \mathrm{~mm}$ grid. For each dish, one or two fields, each containing 10-30 healthy neurons, were selected before treatment, and the healthy neurons in the selected fields were identified. Neurons were perfused continuously with extracellular solution at a rate of $1-2 \mathrm{ml} / \mathrm{min}$. Trypan blue stain was used to assess neuronal death after treatment.

Data are reported as mean $\pm \mathrm{SD}$.

\section{RESULTS}

\section{Prolonged NMDA application triggers $I_{\text {pe }}$ and cell death}

We have shown that with a short $(2-8$ sec, $100 \mu \mathrm{M})$ NMDA application, the holding current returns to baseline after termination of the NMDA application (Chen and Wong, 1995a,b). Figure $1 A$ shows the result of a long $(10 \mathrm{~min}, 100 \mu \mathrm{M})$ NMDA application (exposure). The NMDA response changed kinetics at $5.6 \pm$ $1.4 \min (n=8)$ of NMDA application, with the appearance of a superimposing and continuously increasing inward current accompanied by an increase in membrane conductance. This inward current, which we call the postexposure current $\left(I_{\mathrm{pe}}\right)$, persisted after termination of NMDA application and increased at a rate of $\sim 62 \mathrm{pA} / \mathrm{min}$ throughout the recordings, which ended at 30-40 min postexposure $(n=8$ cells). The input resistance and holding current at $-55 \mathrm{mV}$ were $2.9 \pm 1.1 \mathrm{G} \Omega$ and $-22.5 \pm 10.3 \mathrm{pA}$ before NMDA exposure and $23 \pm 3 \mathrm{M} \Omega$ and $-2.4 \pm 0.3 \mathrm{nA}(n=$ 8 ) at $30 \mathrm{~min}$ after exposure. Cell death was assessed at $30 \mathrm{~min}$ postexposure; all eight cells showed positive trypan blue stain. In four of these eight cells, trypan blue stain was also performed at 0,10 , and $20 \mathrm{~min}$ postexposure; only one neuron showed positive stain at $20 \mathrm{~min}$ postexposure.

\section{A rise in $\left[\mathrm{Ca}^{2+}\right]_{\mathbf{i}}$ induces $\mathrm{I}_{\mathrm{pe}}$}

When cells were bathed in zero-calcium solution during NMDA exposure, no continuously increasing holding current was observed during the postexposure phase (Fig. $1 B$ ). The input resis-
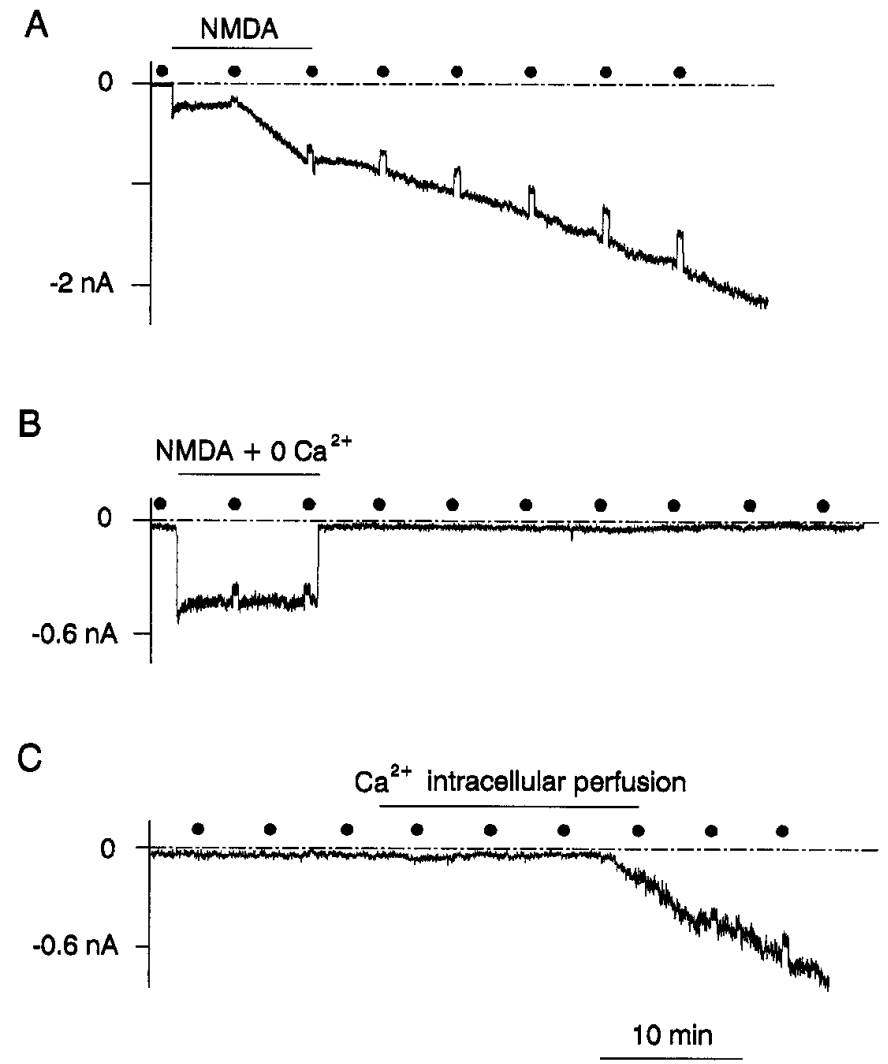

Figure 1. NMDA exposure and rises in $\left[\mathrm{Ca}^{2+}\right]_{\mathrm{i}}$ trigger $I_{\mathrm{pe}} \cdot A$, Response to NMDA exposure $(10 \mathrm{~min}, 100 \mu \mathrm{M})$ in the presence of $\mathrm{Ca}^{2+}{ }_{\mathrm{o}} . B$, Response to NMDA exposure (10 $\mathrm{min}, 100 \mu \mathrm{M})$ in zero-calcium extracellular solution. $C$, Response to intracellular perfusion of high$\mathrm{Ca}^{2+}$ solution. To measure input resistance, voltage steps $(+10 \mathrm{mV}, 30$ $\mathrm{sec})$ were applied once every $5 \mathrm{~min}$ at the times indicated by the circles. These voltage steps have no effect on the development of $I_{\mathrm{pe}}$. Horizontal lines on top of each current trace indicate periods of solution application.

tance and holding current were $2.8 \pm 1.2 \mathrm{G} \Omega$ and $-24 \pm 12 \mathrm{pA}$ before exposure and $2.5 \pm 1 \mathrm{G} \Omega$ and $-29 \pm 19 \mathrm{pA}(n=6)$ after exposure. None of the six neurons stained with trypan blue at 30 min postexposure. The possibility that a rise in $\left[\mathrm{Ca}^{2+}\right]_{\mathrm{i}}$ triggers $I_{\mathrm{pe}}$ was tested further by using the intracellular perfusion technique. Figure $1 C$ shows that an increase in $\left[\mathrm{Ca}^{2+}\right]_{\mathrm{i}}$ caused by an $18 \mathrm{~min}$ intracellular perfusion of high-calcium intracellular solution induced an inward current $(n=7)$. This inward current was indistinguishable from $I_{\mathrm{pe}}$ in its reversal potential and ionic selectivity (see below).

\section{$I_{\text {pe }}$ is a cation current}

To test the ionic basis of $I_{\text {pe }}$, we performed several ion substitution experiments. In the first, replacing $120 \mathrm{~mm}$ extracellular $\mathrm{Cl}^{-}$ with the presumably less-permeant anion gluconate $(120 \mathrm{~mm})$ changed neither the reversal potential of nor the conductance associated with $I_{\text {pe }}$ (Fig. $2 B$ ). In another set of experiments, we created a significant salt gradient across the membrane by applying one of three extracellular isotonic low-salt solutions $(20 \mathrm{~mm}$ $\mathrm{NaCl}, 20 \mathrm{~mm} \mathrm{KCl}$, or $10 \mathrm{~mm} \mathrm{CaCl}_{2}$ ). Reducing the extracellular salt concentration caused a reduction in the amplitude of the inward $I_{\mathrm{pe}}$ (Fig. 2A) and a negative shift in the reversal potential (Fig. $2 C$ ), which is the opposite result of what would be expected if $I_{\mathrm{pe}}$ were an anion current, indicating that the contribution of anion effluxes to $I_{\mathrm{pe}}$ is negligible. The inward $I_{\mathrm{pe}}$ could be obtained 
Figure 2. $I_{\text {pe }}$ is carried by $\mathrm{Ca}^{2+}$ and $\mathrm{Na}^{+} \cdot A-D$, $I_{\mathrm{pe}}$ was triggered by NMDA exposure (10 min, $100 \mu \mathrm{M})$ or intracellular perfusion of highcalcium solution. $A$, Responses of $I_{\mathrm{pe}}$ to changes of extracellular ionic composition. Line above current traces indicates period of perfusion of $20 \mathrm{~mm} \mathrm{NaCl}$ solution, $20 \mathrm{~mm} \mathrm{KCl}$ solution, or $10 \mathrm{mM} \mathrm{CaCl}_{2}$ solution. Changes of $I_{\mathrm{pe}}$ reached a plateau (indication of complete solution change around cell) within $2 \mathrm{sec}$. These responses are not from the same cell; because $I_{\mathrm{pe}}$ grows over time, we chose instead to show responses in which the $I_{\mathrm{pe}}$ amplitudes (directly before the change to test solution) matched. $B$, $C$, Voltage ramps $(-90 \mathrm{mV}$ to $+90 \mathrm{mV}, 600$ msec duration) performed 3-6 sec after changing to the indicated solutions. $B, I_{\mathrm{pe}}$ during the voltage ramp in the presence of extracellular control solution (continuous trace) and low- $\mathrm{Cl}^{-}$ solution (dotted trace). (Traces essentially overlap.) The reversal potentials of $I_{\mathrm{pe}}$ were $0.8 \pm$ $0.6 \mathrm{mV}$ (control solution) and $0.8 \pm 0.7 \mathrm{mV}$ (low- $\mathrm{Cl}^{-}$solution, mean $\pm \mathrm{SD}, n=5$ ). $C, I_{\mathrm{pe}}$ during the voltage ramp in the presence of extracellular control $(a), 10 \mathrm{mM} \mathrm{CaCl} 2(b), 20$ $\mathrm{mm} \mathrm{KCl}(c)$, and $20 \mathrm{~mm} \mathrm{NaCl}(d)$ solutions. During the voltage ramps, TTX $(5 \mu \mathrm{M})$ and $\mathrm{Co}^{2+}(200 \mu \mathrm{M})$ were applied to block voltagedependent $\mathrm{Na}^{+}$and $\mathrm{Ca}^{2+}$ currents. Baseline leak current before NMDA exposure was not subtracted from current traces shown in $B$ and $C$, because the subtraction made no significant difference in the reversal potential or conductance measured. $D$, Neither MK-801 $(20 \mu \mathrm{M})$ nor $\mathrm{Co}^{2+}(200 \mu \mathrm{M})$ suppressed $I_{\mathrm{pe}}$. Voltage steps $(+10 \mathrm{mV})$ were applied every $25 \mathrm{sec}$. Cells examined had an $I_{\mathrm{pe}}$ smaller than $-1 \mathrm{nA}$.

A

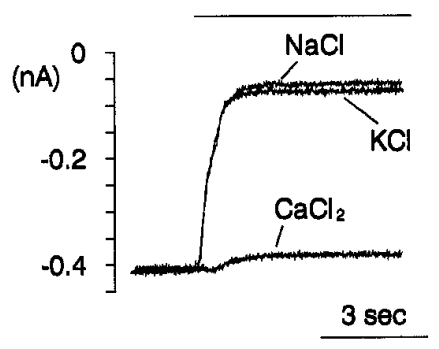

C

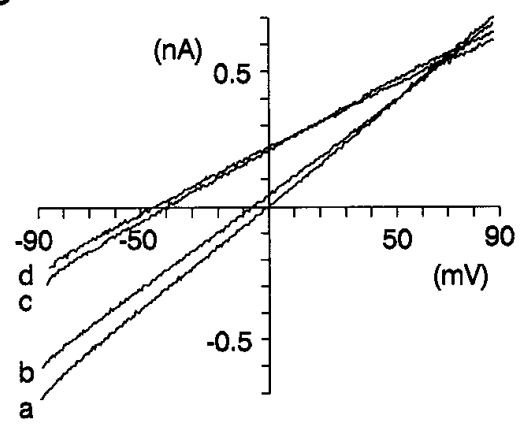

B

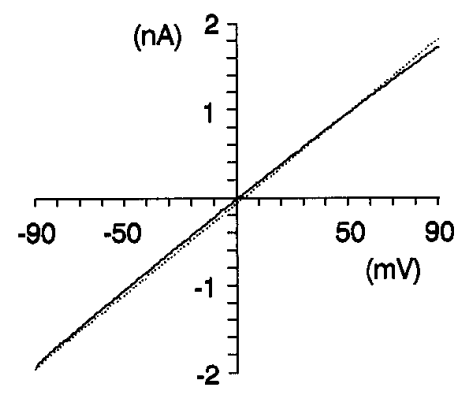

D

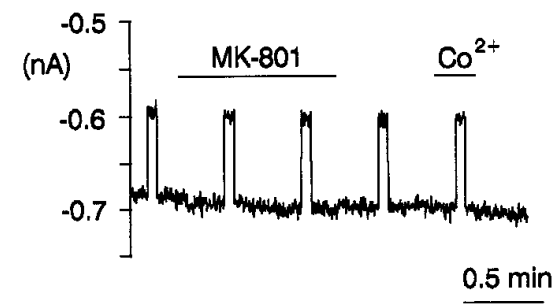

with any single cation tested $\left(\mathrm{Na}^{+}, \mathrm{K}^{+}\right.$, or $\left.\mathrm{Ca}^{2+}\right)$ alone in the extracellular solution (Fig. $2 A, C$ ), indicating that $\mathrm{Na}^{+}, \mathrm{K}^{+}$, and $\mathrm{Ca}^{2+}$ can all carry the inward $I_{\mathrm{pe}}$. With $\mathrm{Cs}^{+}(120 \mathrm{~mm})$ on the intracellular side of the membrane and either $\mathrm{Na}^{+}(20 \mathrm{~mm}), \mathrm{K}^{+}$ (20 $\mathrm{mm})$, or $\mathrm{Ca}^{2+}(10 \mathrm{~mm})$ on the extracellular side of the membrane, the reversal potentials of $I_{\text {pe }}$ were $-45 \pm 0.6,-43 \pm$ 0.8 , and $-5 \pm 0.7 \mathrm{mV}$, respectively (mean $\pm \mathrm{SD}, n=5$ ). With these data, we estimated the relative permeabilities $\mathrm{P}_{\mathrm{Cs}} / \mathrm{P}_{\mathrm{Na}} / \mathrm{P}_{\mathrm{K}} /$ $\mathrm{P}_{\mathrm{Ca}}$ to be 1:0.9:0.9:6.3. The high- $\mathrm{Ca}^{2+}$ permeability and the lack of discrimination among different monovalent cations are comparable with the properties of the NMDA receptor channel (Mayer and Westbrook, 1987). However, blockers for the NMDA receptor channel, MK-801 (20 $\mu \mathrm{M}, 1$ min exposure) and ketamine (20 $\mu \mathrm{M}, 1 \mathrm{~min}$ exposure), had no effect on $I_{\text {pe }}(n=4$; Fig. $2 D)$. In addition, voltage-dependent $\mathrm{Ca}^{2+}$ channel blockers $\mathrm{Co}^{2+}(200$ $\mu \mathrm{M}, 20 \mathrm{sec}$ exposure; Fig. $2 D)$ and nimodipine $10 \mu \mathrm{M}(20 \mathrm{sec}$ exposure), and the $\mathrm{Na}^{+}$channel blocker tetrodotoxin $(5 \mu \mathrm{M}, 10$ sec exposure) all failed to affect the $I_{\mathrm{pe}}(n=4)$.

\section{$I_{\text {pe }}$ is responsible for NMDA toxicity}

We have demonstrated that $I_{\text {pe }}$ was carried by $\mathrm{Ca}^{2+}$ and $\mathrm{Na}^{+}$(Fig. 2 ) and persisted and increased continuously in amplitude during the postexposure phase (Fig. 1A). These properties give $I_{\mathrm{pe}}$ the potential of causing substantial accumulation of $\mathrm{Na}^{+}$and $\mathrm{Ca}^{2+}$ in the intracellular space. Accumulation of both ions, particularly $\mathrm{Ca}^{2+}$, inside a neuron is cytotoxic (Choi, 1988). As presented above, a normally toxic exposure to NMDA does not kill the cells when $I_{\mathrm{pe}}$ is not activated (zero-calcium extracellular solution; Fig. $1 B)$. To further address the causal connection between $I_{\mathrm{pe}}$ and cell death, we tested whether postexposure suppression of $I_{\mathrm{pe}}$ would reduce neuronal death. Without a specific blocker for $I_{\mathrm{pe}}$, we took advantage of the fact that $I_{\mathrm{pe}}$ can be suppressed by the 20 $\mathrm{mm} \mathrm{NaCl}$ solution (see Fig. $2 A$ ). Extracellular perfusion with the $20 \mathrm{~mm} \mathrm{NaCl}$ solution after the NMDA exposure caused an immediate suppression of $I_{\mathrm{pe}}$ of $86 \pm 1 \%(n=8$; Fig. $3 A)$. In addition, perfusion with the $20 \mathrm{~mm} \mathrm{NaCl}$ solution during the postexposure phase prevented the growth of $I_{\mathrm{pe}}$ (Fig. 3A); the change in $I_{\mathrm{pe}}$ amplitude during the $30 \mathrm{~min}$ postexposure phase was $\leq 18 \%(n=8)$ compared with a $\geq 100 \%$ change in $I_{\mathrm{pe}}$ amplitude in control extracellular solution $(n=8)$. None of the cells exposed to the $20 \mathrm{~mm} \mathrm{NaCl}$ solution during the postexposure phase stained with trypan blue at 30 min postexposure $(n=8)$, indicating that suppression of $I_{\mathrm{pe}}$ in the postexposure phase was neuroprotective.

To determine whether $\mathrm{Ca}^{2+}$ and/or $\mathrm{Na}^{+}$influx led to the growth of $I_{\mathrm{pe}}$ and the death of neurons, we removed only $\mathrm{Ca}^{2+}$ from the control extracellular solution during the postexposure phase. Extracellular perfusion with the zero- $\mathrm{Ca}^{2+}$ solution during the postexposure phase prevented the continuous increase in $I_{\mathrm{pe}}$ amplitude (Fig. 3B; compare Fig. 1A). In addition, we observed an immediate $32 \pm 6 \%(n=6)$ increase in $I_{\mathrm{pe}}$, possibly attributable to removing the suppressive effect of $\mathrm{Ca}^{2+}$ o on $\mathrm{Na}^{+}$influx, as observed for other $\mathrm{Ca}^{2+}$-permeable conductances (Mayer and Westbrook, 1987; Lux et al., 1990). Only neurons with $I_{\text {pe }}$ amplitudes larger than $-1 \mathrm{nA}$ immediately after $\mathrm{Ca}^{2+}$ removal (2 of 6 neurons tested) stained with trypan blue at $30 \mathrm{~min}$ postexposure.

Because whole-cell recording disturbs the metabolism of the recorded cell, we tested to make sure that whole-cell recording itself is not necessary for the activation of $I_{\mathrm{pe}}$ and the resulting cell death. Nonrecorded cells (both NMDA-exposed and nonexposed cells in sister dishes) were examined by short-duration whole-cell recording (point recording) performed at different times on dif- 
A

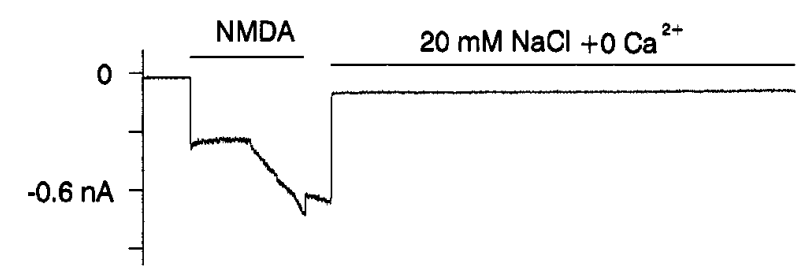

B

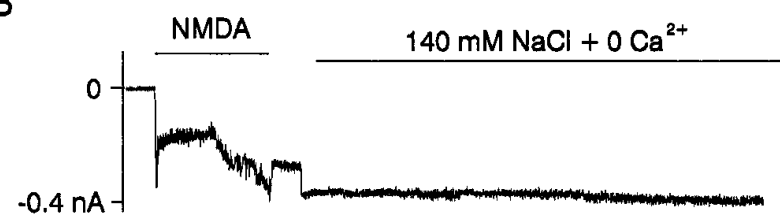

$\underline{5 \mathrm{~min}}$

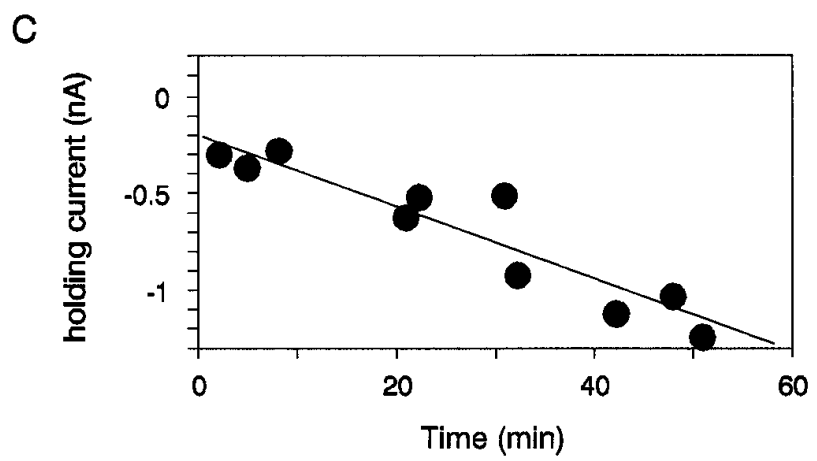

D

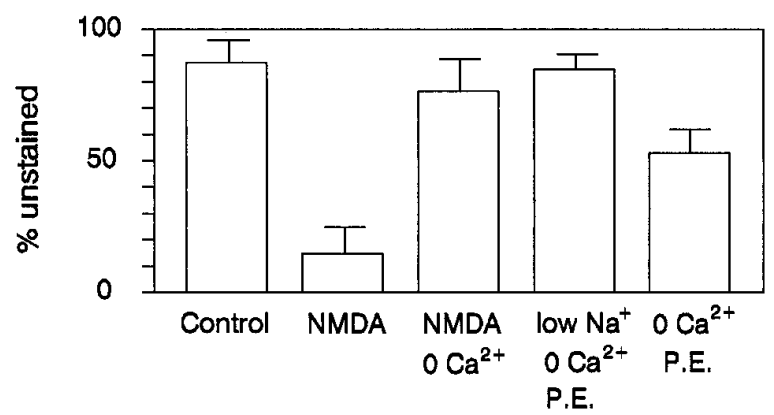

Figure 3. $I_{\mathrm{pe}}$-mediated $\mathrm{Ca}^{2+}$ and $\mathrm{Na}^{+}$influx leads to the death of NMDA-exposed neurons. $A-D, I_{\mathrm{pe}}$ was triggered by NMDA application $(10 \mathrm{~min}, 100 \mu \mathrm{M}) . A$, Response of $I_{\mathrm{pe}}$ to simultaneous removal of $\mathrm{Ca}^{2+}{ }_{\mathrm{o}}$ and reduction of $\left[\mathrm{Na}^{+}\right]_{\mathrm{o}}$ for the postexposure phase (started $1 \mathrm{~min}$ postexposure). $B$, Response of $I_{\text {pe }}$ to removal of $\mathrm{Ca}^{2+}$ o for the postexposure phase. $C$, NMDA exposure triggers a gradually developing $I_{\mathrm{pe}}$ in nonrecorded cells. Healthy pyramidal cells within a field were identified before NMDA exposure and randomly selected at different times postexposure for point recording. Zero time indicates beginning of postexposure phase. Each circle represents a point recording from a different cell in the dish. $D$, Percentage of survival of neurons in sister dishes with the same treatment as those applied to recorded cells. NMDA application and manipulation of extracellular ionic composition were performed by bath perfusion. Healthy neurons in two fields per dish were identified before treatment. To evaluate the percentage of neuronal death after different treatments, trypan blue staining was performed at $60 \mathrm{~min}$ postexposure. The five bars represent average survival values obtained from (left to right) the control group (not exposed to NMDA), the NMDA group (exposed to NMDA), the NMDA $+0 \mathrm{Ca}^{2+}$ group (exposed to NMDA in the presence ferent cells in the dish during the postexposure phase. Point recording showed that NMDA-exposed cells had a smaller input resistance and a larger inward current immediately after disruption of the patch membrane than nonexposed cells. This inward current in NMDA-exposed cells was indistinguishable from $I_{\mathrm{pe}}$. In agreement with data from recorded cells, point recordings also revealed that $I_{\mathrm{pe}}$ grew over time during the postexposure phase in nonrecorded cells (Fig. 3C). The seal resistance of point recordings was the same regardless of whether $I_{\mathrm{pe}}$ was present, indicating that the development of $I_{\mathrm{pe}}$ after NMDA exposure in recorded cells (see Fig. $1 A$ ) is not attributable to a gradual deterioration of the seal. Figure $3 D$ shows results from trypan blue staining performed at $60 \mathrm{~min}$ postexposure on sister dishes of nonrecorded cells that were exposed to the same treatment as recorded cells. Consistent with the results in recorded cells, only protocols shown previously to trigger $I_{\mathrm{pe}}$ caused cell death (i.e., NMDA exposure but not NMDA exposure in zero-calcium solution). In addition, protocols shown to suppress $I_{\text {pe }}$ postexposure (i.e., postexposure removal of $\mathrm{Ca}^{2+}$ o and simultaneous reduction in $\mathrm{Na}^{+}{ }_{\mathrm{o}}$ ) or the growth of $I_{\mathrm{pe}}$ during the postexposure (i.e., postexposure removal of $\mathrm{Ca}^{2+}{ }_{\mathrm{o}}$ ) caused a significant reduction in the percentage of dead cells. The solution containing zero-calcium and low- $\mathrm{Na}^{+}$(the 20 $\mathrm{mm} \mathrm{NaCl}$ ) solution provided the greatest postexposure protection, producing a survival rate indistinguishable from control (Fig. 3D).

\section{DISCUSSION}

Ipe

NMDA application caused the appearance of the cation current $I_{\text {pe }}$, which persisted and increased in size after the removal of NMDA. The strict cation selectivity and differential permeability of $I_{\mathrm{pe}}$ indicate that $I_{\mathrm{pe}}$ is not simply the result of a breakdown of membrane integrity, but is rather associated with a well-behaved membrane conductance. The fact that induction of $I_{\mathrm{pe}}$ required the presence of extracellular $\mathrm{Ca}^{2+}$ during NMDA exposure indicates that $I_{\mathrm{pe}}$ is triggered by $\mathrm{Ca}^{2+}$ entry through NMDA receptor channels, a conclusion that is supported by the experiments that showed that intracellular perfusion with $\mathrm{Ca}^{2+}$ could also lead to the activation of $I_{\mathrm{pe}}$. Because $I_{\mathrm{pe}}$ is itself partly carried by $\mathrm{Ca}^{2+}$, $\mathrm{Ca}^{2+}$ entry associated with $I_{\mathrm{pe}}$ could induce additional $I_{\mathrm{pe}}$. In fact, removing the $\mathrm{Ca}^{2+}$ from the extracellular solution during postexposure prevented the gradual growth in $I_{\text {pe }}$ (Fig. $3 A, B$ ), indicating that continued $I_{\mathrm{pe}}$-mediated $\mathrm{Ca}^{2+}$ influx is responsible for the continuous increase in the size of $I_{\mathrm{pe}}$. On the other hand, a large $I_{\text {pe }}$ persisted (but did not increase in amplitude) when zero- $\mathrm{Ca}^{2+}$ solution was perfused during the postexposure phase (Fig. $3 B$ ), indicating that continued $\mathrm{Ca}^{2+}$ influx is not required for the maintenance of $I_{\mathrm{pe}}$. The activation requirements and properties of $I_{\mathrm{pe}}$ indicate that it is probably responsible for the secondary $\left[\mathrm{Ca}^{2+}\right]_{\mathrm{i}}$ increase which has been recorded in response to gluta-

$\leftarrow$

of zero $\mathrm{Ca}^{2+}{ }_{\mathrm{o}}$ ), the low- $\mathrm{Na}^{+}+0 \mathrm{Ca}^{2+}$ postexposure group (exposed to NMDA and then bathed in the $20 \mathrm{~mm} \mathrm{NaCl}$ solution during postexposure), and the $0 \mathrm{Ca}^{2+}$ postexposure group (exposed to NMDA and then bathed in zero-calcium solution during postexposure). Consistent with data obtained from recorded cells, postexposure removal of $\mathrm{Ca}^{2+}{ }_{\mathrm{o}}$ reduced neuronal death caused by NMDA exposure $\left(0 \mathrm{Ca}^{2+}\right.$ postexposure group vs NMDA group, $p<0.01)$. Postexposure reduction of $\left[\mathrm{Na}^{+}\right]_{\mathrm{o}}$ in addition to removing $\mathrm{Ca}^{2+}$ o provided additional protection (low- $\mathrm{Na}^{+}+$ $0 \mathrm{Ca}^{2+}$ postexposure group vs $0 \mathrm{Ca}^{2+}$ postexposure group, $\left.p<0.01\right)$ and was not significantly different from control $(p>0.05)$. Error bars represent SD ( $n=12$ fields, 2 fields from each of 6 animals). Student's two-tailed $t$ test was used to obtain $p$ values. 
mate exposure (Randall and Thayer, 1992; Tymianski et al., 1993). Additional studies are needed to address the microscopic conductance and modulatory mechanisms associated with $I_{\mathrm{pe}}$.

\section{$I_{\text {pe }}$ and neuronal death}

Earlier investigations in cultured neurons have shown that cell death from NMDA application is markedly reduced if the NMDA is applied in zero-calcium solution (Choi, 1987). In addition, earlier studies in cultured neurons have shown that removal of extracellular calcium $\left(\mathrm{Ca}^{2+}{ }_{\mathrm{o}}\right)$ in the postexposure phase reduces neuronal death (Hartley and Choi, 1989; Manev et al., 1989), and that simultaneous removal of $\mathrm{Ca}^{2+}{ }_{\mathrm{o}}$ and $\mathrm{Na}^{+}{ }_{\mathrm{o}}$ during the postexposure phase produces essentially complete blockade of NMDA neurotoxicity (Hartley and Choi, 1989). Our study has replicated these results in a new system and, more importantly, has shown that these two procedures block NMDA toxicity in acutely isolated hippocampal cells, because the first prevents the induction of $I_{\mathrm{pe}}$ and the second suppresses $I_{\mathrm{pe}}$ in the postexposure phase. Our results indicate that NMDA exposure causes an initial $\mathrm{Ca}^{2+}$ influx that triggers the onset of $I_{\mathrm{pe}}$ and that it is the large and persistent secondary influx of $\mathrm{Ca}^{2+}$ and $\mathrm{Na}^{+}$underlying the $I_{\mathrm{pe}}$ that is the downstream event associated with cell death.

Previous studies (Choi, 1987) have measured "delayed" cell death, in which cultured neurons exposed to glutamate or NMDA die several hours later. Our experiments cannot be said to measure delayed cell death, because the NMDA-exposed cells died within $1 \mathrm{hr}$; in fact, acutely isolated hippocampal cells will die in 2-4 hr without NMDA exposure. Regardless, it is possible that $I_{\mathrm{pe}}$ may contribute to NMDA-induced delayed cell death in other systems. The existence of an $I_{\mathrm{pe}}$ in other systems could account for the NMDA antagonist-insensitive sustained increase in $\left[\mathrm{Ca}^{2+}\right]_{\mathrm{i}}$, which has been correlated with cell death (de Erausquin et al., 1990; Randall and Thayer, 1992; Tymianski et al., 1993) and for the protection of neurons seen with the simultaneous removal of $\mathrm{Na}^{+}$and $\mathrm{Ca}^{2+}$ in the postexposure phase (Hartley and Choi, 1989). Because the $\mathrm{Na}^{+}$and $\mathrm{Ca}^{2+}$ influx associated with $I_{\text {pe }}$ may be the downstream event that causes glutamate neurotoxicity, pharmacological agents that could suppress $I_{\mathrm{pe}}$ or retard its growth may reduce cell death.

\section{REFERENCES}

Celentano JJ, Wong RKS (1994) Multiphasic desensitization of the $\mathrm{GABA}_{\mathrm{A}}$ receptor in outside-out patches. Biophys J 66:1039-1050.

Chen QX, Wong RKS (1995a) Suppression of a $\mathrm{Ca}^{2+}$ current by NMDA and intracellular $\mathrm{Ca}^{2+}$ in acutely isolated hippocampal neurons. J Neurophysiol 73:515-524.
Chen QX, Wong RKS (1995b) Suppression of $\mathrm{GABA}_{\mathrm{A}}$ receptor responses by NMDA application in hippocampal neurones acutely isolated from the adult guinea-pig. J Physiol (Lond) 482:353-362.

Chen QX, Stelzer A, Kay AR, Wong RKS (1990) GABA $_{\mathrm{A}}$ receptor function is regulated by phosphorylation in acutely dissociated guineapig hippocampal neurons. J Physiol 420:207-221.

Choi DW (1987) Ionic dependence of glutamate neurotoxicity. J Neurosci 7:369-379.

Choi DW (1988) Calcium-mediated neurotoxicity: relationship to specific channel types and role in ischemic damage. Trends Neurosci 11:465-469.

de Erausquin GA, Manev H, Guidotti A, Costa E, Brooker G (1990) Gangliosides normalize distorted single-cell intracellular free $\mathrm{Ca}^{2+}$ dynamics after toxic doses of glutamate in cerebellar granule cells. Proc Natl Acad Sci USA 87:8017-8021.

Faden AI, Demediuk P, Panter SS, Vink R (1989) The role of excitatory amino acids and NMDA receptors in traumatic brain injury. Science 244:798-800.

Graham SH, Chen J, Simon RP (1993) A dose-response study of dextrorphan in permanent focal ischemia. Neurosci Lett 160:21-23.

Hamill OP, Marty A, Neher E, Sakmann B, Sigworth FJ (1981) Improved patch-clamp techniques for high-resolution current recording from cells and cell-free membrane patches. Pflüegers Arch 391:85-100.

Hartley DM, Choi DW (1989) Delayed rescue of $N$-methyl-D-aspartate receptor-mediated neuronal injury in cortical culture. J Pharmacol Exp Ther 250:752-758.

Kay AR, Wong RKS (1986) Isolation of neurons suitable for patchclamping from adult mammalian central nervous systems. J Neurosci Methods 16:227-238.

Lux HD, Carbone E, Zucker H (1990) $\mathrm{Na}^{+}$currents through lowvoltage-activated $\mathrm{Ca}^{2+}$ channels of chick sensory neurones: block by external $\mathrm{Ca}^{2+}$ and $\mathrm{Mg}^{2+}$. J Physiol (Lond) 430:159-188.

Manev H, Favaron M, Guidotti A, Costa E (1989) Delayed increases of $\mathrm{Ca}^{2+}$ influx elicited by glutamate: role in neuronal death. Mol Pharmacol 36:106-112.

Mayer ML, Westbrook GL (1987) Permeation and block of $N$-methyl-Daspartic acid receptors by divalent cations in mouse cultured central neurones. J Physiol (Lond) 394:501-527.

Meldrum BS (1994) The role of glutamate in epilepsy and other CNS disorders. Neurology 44[Suppl 8]:S14-S23.

Neher E (1992) Correction for liquid junction potentials in patch clamp experiments. Methods Enzymol 207:123-131.

Randall RD, Thayer SA (1992) Glutamate-induced calcium transient triggers delayed calcium overload and neurotoxicity in rat hippocampal neurons. J Neurosci 12:1882-1895.

Simon RP, Swan JH, Griffiths T, Meldrum BS (1984) Blockade of $N$-methyl-D-aspartate receptors may protect against ischemic damage in the brain. Science 226:850-852.

Tymianski M, Charlton MP, Carlen PL, Tator CH (1993) Secondary $\mathrm{Ca}^{2+}$ overload indicates early neuronal injury which precedes staining with viability indicators. Brain Res 607:319-323.

Wieloch T (1985) Hypoglycemia-induced neuronal damage prevented by an $N$-methyl-D-aspartate antagonist. Science 230:681-683. 